\title{
THE USE OF PROPHYLACTIC SYSTEMIC ANTIBIOTICS IN COMPOUND DEPRESSED SKULL FRACTURES IN INFANCY AND CHILDHOOD
}

\author{
J. PINDARO P. PLESE * \\ ROBIN P. HUMPHREYS **
}

The use of prophylactic antibiotics in compound depressed skull fractures (CDSF) is not generally accepted $2,4,5,7,12$. The great majority of pediatric neurosurgeons recommend systemic prophylactic antibiotics when fractures are open or when bone fragments are replaced, to prevent local and systemic infection 3,8,10,11,12,14.

The purpose of this paper is to report our experience with the treatment of 60 patients with CDSF younger than 13 years treated in the hospital from 1970 to 1980. The results of the treatment of these patients with and without systemic prophylactic antibiotics and the correlation of the infection rate with and without the replacement of bone fragments were discussed.

\section{CLINICAI MATERIAI}

60 patients with CDSF (36 from Toronto and 24 from Săo Paulo) were inc̀luded in this study, 35 were boys and 21 girls and the age ranged from 3 to 13 years old and underwent four kinds of treatment. The patients were divided into 4 groups with 15 patients each.

1st group - patients receive systemic antiblotics, and bone fragments were discarted; 2nd group - patients didn't receive systemic antibiotics and bone fragments were discarted; 3rd group - patlents recelve systemic antlbiotics and bone fragments were replaced; 4th group - patients didn't recelve systemic antiblotics and bone fragments were replaced.

In all cases the surgical treatment was carried out during the first 24 hours after the accident. The first aids were the same in all cases. During the preoperative phase a coplous washing with Phisiohex and saline solution of the slicull and wound were performed. The operative procedure consisted of debridement of the wounds and of the usual treatment of the dural laceration and/or laceration of the brain. Irrigation with Bacitracin and saline solution was made in all cases from Toronto and Gentamicin and saline solution in all cases from sao Paulo.

* Neurosurgeon Assistant Professor, Neurologic Clinic, Neuropsychiatry Department, Săo Paulo University (Brasil).

** Neurosurgeon Assistant Professor. Department of Surgery, University of Toronto (Canada). 
All patients had akin wound, 57\% had dura torn and $39 \%$ laceration of the brain. Half of the patients had the bone fragments replaced.

In all the four groups during a period ranging from 6 months to 9 years, no infection was detected, in $32 \%$ of the patients of the 1st and 2nd groups a cranioplastjc treatment was necessary.

\section{DISCUSBION}

Matson 10 advogated the use of prophylactic antibiotics and the discharge of the bone fragments, to prevent local or intracranial infection in children with CDSF. This idea was adopted by other authors 5.11,12. Miller \& Janett 12 report only $10 \%$ of infection with this procedure.

Braakman 2 and Jamieson \& Yelland 4 could not discern any difference in the infection rate with or without administration of routine systemic antibiotics.

Alexander 1 has the opinion that the bone fragments should be discarted and a cranioplasty done at a later time, if necessary. He does't recomend the use of -prophylactic antibiotics.

Kriss, Taren \& Kahn ${ }^{6}$ and Till ${ }^{14}$ recomend the replacement of the bone fragments and the use of prophylactic systemic antibiotics only when infection is suspected or if formal debridement has to be delayed for some particular reason.

\section{CONCLUSION}

The analysis of our series showed:

1 - the rate of infection in CDSF with or without systemic prophylactic antibiotics was $0 \% ; 2$ - the use of prophylactic antibiotics in children with CDSF does't influence incidence of early or late infection; 3 - the replacement of bone fragments does not promote early or late infection; 4 - the most important procedure is an operation performed within the first 24 hours. A meticulous washing of the scalp and a careful debridement of the skin wound, periosteum, dura-mater and, if necessary, of the brain tissue are essential to prevent infections. The irrigation of the skin wound and of the bone fragments with saline solution with antiseptic drug is another method usefull for the prevention of infections.

\section{SUMMARY}

The authors described their experience with the use of prophylactic antibiotics in children with compound depressed skull fractures. The analysis of the results of the treatment of patients with or without systemic antibiotics and with or without the replacement of the bone fragments showed no difference in the infection rate, any one was the method used. 


\section{RESUMO}

Uso profilático de antibióticos em fraturas cranianas com afundamentos $e$ cominutivas na infância.

Os autores relatam sua experiência com o uso de antibióticos profiláticos sistemicos em crianças portadoras de fraturas cranianas com afundamentos e cominutivas. Não detectaram infecção precoce ou tardia nos pacientes que receberam antibióticos sistemicos e nos que não receberam e também relação com a recolocação ou não dos fragmentos ósseos.

\section{REFERENCES}

1. ALEXANDER, E. Jr. - Surgical management of head injuries in children in the acute phase. In Clinial Neurosurgery Ed. George T. Tindall. Williams \& Wilkins, Baltimore 1972, pp. 251-262.

2. BRAAKMAN, R. - Depressed skull fracture: data, treatment and follow-up in 225 consecutive cases. J. Neurol. Neurosurg. Psychiat. (Chicago) 35:395, 1972.

3. CARRINGTON, K. W.; TAREN, J. A. \& KAHN, E. A. - Primary repair of compound skull fractures in children. Surgery Gynec. Obstet. 110:203, 1960.

4. JAMIESON, K. G. \& YelLAND, J. D. N. - Depressed skull fractures in Australia. J. Neurosurg. 37:150, 1972.

5. JENNET, W. B. \& MILLER, O. D. - Infection after depressed fracture of the skull: implication for management of nonmissile injurles. J. Neurosurg. 36:333, 1972.

6. KRISS, F. C.; TAREN, J. A. \& KAHN, E. A. - Primary repair of compound skull fractures by replacement of bone fragments. J. Neurosurg. 30:698, 1969.

7. LEWIN, W. - The Management of Head Injurles. Balliere, Tindall \& Cassell, London 1968.

8. LOESER, J. D.: KILBURN, H. L. \& JOLLEY, T. - Management of depressed skull fracture in the newborn. J. Neurosurg. 44:62, 1976.

9. LYERELY, J. G. - The treatment of depressed fractures of the skull with special reference to repair of cranial defect. Am. Surg. 23:1.115, 1957.

10. MATSON, D. D. - Neurosurgery of Infancy and Childhood. Charles C. Thomas, Springfield (Illinois) 1979.

11. Milhorat, T. H. - Pediatric Neurosurgery. F. A. Davis Company, Philadelphia 1978.

12. MILLER, J. D. \& JENNETT, W. B. - Complications of depressed skull fractures. Lancet 2:991, 1968.

13. NADELL, J. \& KLINE, D. G. - Primary reconstruction of depressed frontal skull fractures including those involving the sinus, orbit and cribiform plate. J. Neurosurg. 41:200, 1974.

14. TILL, K. - Pediatric Neurosurgery. Blackwell Scientific Publications, Oxford, 1975.

Clinica Neurolboica - Iraculdade de Medicina, Universidade de sao Paulo - Caixa Postal $\$ 461$ - 01000 8do Paulo; SP - Brasil. 